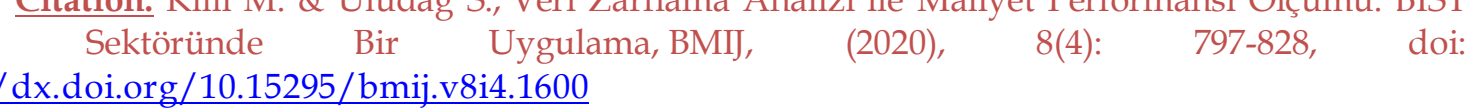

http://dx.doi.org/10.15295/bmij.v8i4.1600

\title{
VERİ ZARFLAMA ANALİZİ İLE MALIYYET PERFORMANSI ÖLÇÜMÜ: BIST TEKSTİL SEKTÖRÜNDE BİR UYGULAMA ${ }^{1}$
}

Mustafa KILLI 2

Sümeyye ULUDAĞ 3

\author{
Received Date (Başvuru Tarihi): \\ Accepted Date (Kabul Tarihi): \\ Published Date (Yayın Tarihi):
}

$24 / 08 / 2020$

$25 / 10 / 2020$

$10 / 12 / 2020$
$\ddot{O Z Z}$

\section{Anahtar Kelimeler:}

Yönetim Muhasebesi,

Maliyet Performansı Ölçümü,

Veri Zarflama Analizi
Küreselleşen dünyada işletmelerin rakipleri ile rekabet edebilmeleri için maliyet üstünlüğ̈̈ sağlamalan gerekmektedir. Geçmiş verilerden elde edilen maliyet sonuçlan ile maliyet performans ölçümleri yapılması işletme yöneticilerinin geleceğe ilişkin daha doğru karar almasına yardımcı olacaktır. Çalışmanın amacı tekstil, giyim eşyası ve deri sektöründe faaliyette bulunan işletmelerin maliyet performanslarmı ölçerek, mevcut durumların belirlemek ve işletmelerin gelecekte daha etkin hale gelebilmeleri için öngörüde bulunmaktır. İsletmeler arasında gerçekleşen kıyaslama sonucunda, etkin olmayan tekstil işletmelerinin girdi düzeylerinde iyileştirme yapılmast, etkin olmayan işletmeler için referans seti tespit edilerek ve yönetim muhasebesi kapsamında da yöneticilere yol göstermesi amaçlanmaktadır. Çalışmamızda Borsa İstanbul (BIST)'da işlem gören tekstil, giyim eşyası ve deri sektöründe yer alan 19 adet işletmenin 2017-2019 yillarn finansal tablolarndan elde edilen maliyet verileri ile aynı sektörde kıyaslama imkânı sağlayan, birden fazla girdi ve çıtı kullanılabilen en popüler performans ölçüm yöntemlerinden biri olan Veri Zarflama Analizi (VZA) uygulanarak işletmelerin maliyet etkinlik ölçümü yapılmıştır. İşletmeler etkinliklerine göre sıralanmıştır. İşletmeler arasında etkinlik değerleri yıllara göre farklılık göstermiştir. 2 işletmenin incelenen yıllarda ölçek verimlilikleri etkin çıkarken, diğger işletmeler etkinliklerini düzenli olarak sürdürememiştir.
Keywords:

JEL Codes:
Management Accounting

M40
Cost Performance Measurement

Data Envelopment

Analysis

\footnotetext{
${ }^{1}$ Bu çalışma Osmaniye Korkut Ata Üniversitesi Sosyal Bilimler Enstitüsü İşletme Anabilim Dalında hazırlanan “Veri Zarflama Analizi ile Maliyet Performansı Ölçümü: BIST Tekstil Sektöründe Bir Uygulama" adlı Yüksek Lisans tezinden üretilmiştir.

2 Doç. Dr. Osmaniye Korkut Ata Üniversitesi, İ̈BF, mkilli@osmaniye.edu.tr, https:// orcid.org./0000-0002-9283-9852

${ }^{3}$ Dr. Öğrencisi, Osmaniye Korkut Ata Üniversitesi, SBE, sumeyyeuludag8@gmail.com, https:/ / orcid.org./0000-0001-9301-0539
}

Business \& Management Studies: An International Journal Vol.:8 Issue:4 Year:2020, 797-828

Bu makale, araştırma ve yayın etiğine uygun hazırlanmış ve 


\section{EXTENDED ABSTRACT}

\section{COST PERFORMANCE MEASUREMENT WITH DATA ENVOLEPMENT ANALYSIS: AN IMPLEMENTATION IN BIST TEXTILE SECTOR}

\section{LITERATURE}

\subsection{RESEARCH SUBJECT}

Regardless of the sector, they operate in, ensuring and measuring efficiency in businesses has become increasingly important in recent years. In particular, the global competitive environment forces businesses to use resources effectively and efficiently. For this reason, businesses need to evaluate their performance in the sector in which they operate, compare their effectiveness with their competitors and update their strategies in this context.

There are many studies in domestic and foreign literature about businesses operating in the Textile, Clothing and Leather sector. In the studies conducted by Çetin (2006), Sarıçam and Erdumlu (2012), Demir (2013), Verma, Kumavat and Biswas (2015), data envelopment analysis (DEA) was performed in the field of textile and ready-to-wear industry. Relatively efficient enterprises were determined by comparing the performance of the sectors. Also, as a result of the performance analysis, it was concluded that investments in the technological field should generally increase, resources should not be wasted, and the resources should be fully utilized in order to reduce inefficient resource use and provide better performance.

\subsection{RESEARCH PURPOSE AND IMPORTANCE}

The study aims to measure the cost performance of the enterprises operating in the textile, clothing and leather sector, to determine their current status and to make predictions for the businesses to become more effective in the future. As a result of the comparison between enterprises, it is aimed to improve the input levels of inefficient textile enterprises, to identify a reference set for ineffective enterprises and to guide managers within the scope of management accounting.

\subsection{CONTRIBUTION of the ARTICLE to the LITERATURE}

As a result of DEA applied to textile enterprises traded in BIST, it has been tried to contribute to the literature by making ineffective enterprises effective and making comments about the performances of the enterprises in terms of competition.

\section{DESIGN AND METHOD}

\subsection{RESEARCH TYPE}

The most commonly used non-parametric method is the DEA technique developed by Charnes, Cooper and Rhodes in 1978 (Seyrek \& Ata, 2010, p.69). DEA has emerged as an alternative to regression analysis for efficiency. One of the most significant advantages of the DEA method is that it provides the opportunity to process more than one input and output in the same analysis. DEA is a method that provides quick and easy performance measurement for analysts. It transforms multiple input and output values into a single efficiency value. With the interpretation of the results, individual suggestions are made, and it helps decision-makers to take economic measures (Frehe, 2013).

\subsection{RESEARCH PROBLEMS}

This research tries to reveal how the increase or decrease in costs of textile companies will affect performance.

\subsection{DATA COLLECTION METHOD}

The financial ratios used in the analysis were obtained from the financial statements of the companies examined within the scope of the research. The financial statements of the companies were obtained from the website of the Turkish Public Disclosure Platform. 


\subsection{QUANTITATIVE / QUALITATIVE ANALYSIS}

In the analysis made within the scope of the research, DEA is used. The cost-effectiveness of enterprises was measured by applying DEA, which is one of the most popular performance measurement methods that allow comparison in the same sector and can use more than one input and output.

\subsection{RESEARCH MODEL}

The choice of model depends on the input and output variables. If control over input is less, an output-oriented model should be used, if control over output is less, an input-oriented model should be used (Demir, 2013, p.64). Input-oriented models determine how much inefficient decision-makers should reduce their inputs to achieve a certain level of output. Output-oriented models, on the other hand, are models that try to determine how much output should be increased in order to ensure the effectiveness of ineffective decision units with a given combination of inputs (Akyüz, Yıldırım, \& Balaban, 2015, p. 29).

\section{FINDINGS AND DISCUSSION}

\subsection{FINDINGS as a RESULT of ANALYSIS}

When the 2017 analysis of the enterprises was examined under a fixed scale, five enterprises were found effective. When examined under the variable scale, nine enterprises were found effective. Considering the effectiveness of the scale in 2017, 5 enterprises were effective. In 2018, 5 enterprises were effective under the fixed scale assumption, while ten enterprises were found effective under the variable scale assumption. Looking at scale efficiency in 2018, 5 enterprises were found effective. In 2019,7 businesses on a fixed scale were effective, while ten businesses on a variable scale were effective. When the scale efficiency of 2019 was evaluated, it was concluded that 7 enterprises were effective. It has been determined that scale efficiency is effective in BLCYT and YATAS enterprises within the three years examined. In the years examined, the BLCYT enterprise was ranked first by referencing 25 times by other businesses. The efficiency of 2017 input and output values with DEA was evaluated and analyzed with the input-oriented BCC scale. Six enterprises are said to be effective because the efficiency measurement of BLCYT, DERIM, MNDRS, SNPAM, YATAS and YUNSA companies is found to be one as a result of the analysis. BLCYT, DERIM, MNDRS, SNPAM and YATAS firms were found useful on the CCR scale as DEA analysis results also gave fixed scale returns. As a difference, YUNSA firm was not effective in CCR scale, while BCC was useful on the scale. Since the scale efficiency value is found in the form of CCR / BCC, the scale efficiency of companies that are effective in both scales is 1. If we evaluate the efficiency results of the scale, five companies, namely BLCYT, DERIM, MNDRS, SNPAM and YATAS, are considered adequate.

When the variable scale efficiency for 2017 was evaluated, it was determined that 10 out of 19 businesses were below the efficiency limit. There are ten inactive companies, namely ATEKS, ARSAN, BRKO, BRMEN, BOSSA, HATEK, KRTEK, KORDS, RODRG, SKTAS. The efficiency value of ATEKS, which is among the ineffective enterprises, is expressed as 0.796 , which is 0.204 less efficient than the closest decision-making unit in the market. According to the average values, the scale efficiency average of 19 enterprises has a value of 0.840 , and this value is close to 1 , which is the efficiency limit, shows that the companies operating in the textile sector generally work close to the effect in 2017.

When evaluated on the CCR (total efficiency) scale in 2018, five enterprises are effective, namely BLCYT, BOSSA, KRTEK, YATAS and YUNSA. When evaluated with the BCC (technical efficiency) scale, ten companies, namely BLCYT, BRMEN, BOSSA, DERIM, DESA, KRTEK, MNDRS, RODRG, YATAS and YUNSA, were found useful. According to the scale efficiency values; BLCYT, DERIM, MNDRS, SNPAM, and YATAS enterprises have been found useful. According to their average values, it can be said that the scale efficiency of 19 enterprises decreased compared to 2017 since the scale efficiency average of 2018 was 0.744 .

When efficiency was measured with the CCR scale in 2019, seven businesses, BLCYT, BOSSA, MNDRS, RODRG, SNPAM, YATAS and YUNSA, were found useful. When evaluated with the BCC scale; BLCYT, SNPAM, YATAS, YUNSA, MNDRS, RODRG, BOSSA, DAGI, DERIM, DESA companies are active. Seven firms, namely BLCYT, BOSSA, SNPAM, YATAS, YUNSA, MNDRS, RODRG, are active according to the scale efficiency values. According to the average values of 2019, the scale 
efficiency average of 19 enterprises has a value of 0.858 , showing that it is more effective compared to 2017 and 2018.

\section{CONCLUSION, RECOMMENDATION AND LIMITATIONS}

\subsection{RESULTS of the ARTICLE}

In this study, the cost performance of companies listed in the BIST Textile Sector between 2017 -2019 was analyzed using DEA. As a result of the analysis, while the scale efficiencies of two enterprises among the companies were influential in the years examined, other enterprises could not continue their activities regularly.

\subsection{SUGGESTIONS BASED on RESULTS}

For 2019 BRKO firm 41\% in G1 (cost of sales/sales), 69\% in G2 (management expenses/sales), $41 \%$ in G3 (marketing expenses), BRMEN firm up to 74\% in G2 HATEK firm will be able to take an active position if it reduces $28 \%$ in G1 and G3 and 38\% in G2. The cost of sales within the sales of these enterprises, general management and marketing, sales and distribution expenses have an essential place. When evaluated in general, it can be suggested to ineffective businesses to reduce their costs and significantly to develop strategies to reduce the cost of sales.

\subsection{LIMITATIONS of the ARTICLE}

This study was conducted by using the financial data of the textile companies listed in Borsa Istanbul. Only data available for a three-year period based on the textile sector are considered. The study can be re-expanded for different sectors, period and models. It should also be considered that the financial data of companies not listed on the stock exchange will differentiate the results of their analysis. 


\section{GİRIŞ}

Yönetim muhasebesi ile yöneticiler, işletme kuruluş hedeflerini yerine getirme ve karar almalarına yardımcı olan finansal ve finansal olmayan bilgileri ölçme, analiz etme ve raporlama sürecine (Horngren, Datar \& Rajan, 2015, s.26) katkı sağlamaktadır. İşletme yönetimiyle muhasebe arasında köprü görevi gören yönetim muhasebesi, yöneticilerin doğru ve sağlıklı karar alabilmesi için gerekli sayısal verileri elde etmesini sağlar. Bu bağlamda, bilgilerin ham veri şeklinde toplanmasından, uygun raporlar haline dönüştürülme aşamasına kadar yapılan tüm muhasebe çalışmaları bu alana girmektedir. Yöneticiler için gerekli olan bilgi, yönetim muhasebesini yönlendiren en temel etkendir. Yapılan tüm uygulama ve hazırlanan raporlar genel kabul görmüş ilke, kavram ve kurallar, muhasebe standartları ve yasal hükümlere uygun olup olmamasından ziyade, öncelikle yöneticilerin ihtiyaçlarını karşılaması yönetim muhasebesi açısından daha önemlidir (Coşkun Arslan ve Karkacıer, 2019, s.433).

Yönetim muhasebesi, doğru ve eş zamanlı yürütülen faaliyetler sonucu üretilen bilgileri kullanırken, işletme performansının verimli bir şekilde iyileştirilmesi hedeflenir. Yönetim muhasebesi sadece finansal verileri ölçmekle kalmaz aynı zamanda ürün tasarımı, inovasyon konuları, çalışan motivasyonu, müşteri memnuniyeti ve sadakati, süreç kalitesi, yeni pazar arayışı ve pazarlama kararlarında uyumu sağlama gibi finansal olmayan konularda da yönetim muhasebesi kararları kullanılmaktadır. Ürün tasarımından, ürün satışına kadar olan tüm süreç hatta satış sonrası görüşler yönetim muhasebesinin ilgi alanındadır (Kaygusuz ve Dokur, 2015, s.2).

Ekonomide gerçekleşen gelişme ve değişmeler karşısında klasik yöntemler yetersiz kalınca, modern yöntemlerden biri olan stratejik yönetim önemli rol oynamaktadır. Ulusal ve uluslararası bağlamda rekabet gücü genel verimlilik düzeyini ve maliyet üstünlüğünü etkilemiştir. İşletmeler değişen koşulları izleyip, rekabet üstünlüklerini arttırmak zorundadır.-Stratejik yönetim muhasebesi sosyal, siyasi ve ekonomik gelişmelerin rakipler üzerindeki etkisinin göreceli olarak değerlendirmesine ve yönetimin uzun vadeli stratejik planlar yapmasına yardımcı 
olmaktadır. Geleneksel muhasebe ve stratejik yönetim muhasebesi kıyaslandı̆̆ında; dış çevre ve pazara ilişkin bilgiler alınmasında, işletmelerin maliyet yapılarını incelemede ve izlediği stratejiler konusunda elde edilen bilgilerin incelenip analizinin yapılmasında stratejik yönetim muhasebesi, yöneticilere doğru kararlar vermesini sağlamaktadır (Ergin ve Elmacı, 1999, s.42-43).

Hangi sektörde faaliyet gösterirse göstersin işletmelerde etkinliğin sağlanması ve ölçülmesi son yıllarda giderek önem kazanmaya başlamıştır. Özellikle küresel rekabet ortamı işletmeleri, kaynakları etkin ve verimli bir şekilde kullanmaya zorlamaktadır. İşletmelerin kaliteden taviz vermeden daha az girdiyle daha çok çıktı elde ederek maliyet üstünlüğü elde etmeleri ve etkinliklerini artırmaları mümkün olacaktır. Bu nedenle işletmelerin faaliyette bulunduğu sektör içinde performanslarını değerlendirmeleri, rakipleriyle etkinlik karşılaştırması yapabilmeleri ve bu bağlamda stratejilerini güncellemeleri gerekmektedir.

Bu çalışmada girdi ölçüsü olarak maliyetler ve çıktı ölçüsü olarak kâr kullanılarak maliyet performansı ölçülmek istenmiştir. Bu amaçla BIST Tekstil, Giyim Eşyası ve Deri sektöründe yer alan 19 adet işletmenin 2017-2019 yılları finansal tablolarından elde edilen maliyet ve kârlılık verileri ile sektörel kıyaslama imkânı sağlayan performans ölçüm yöntemlerinden biri olan Veri Zarflama Analizi (VZA) uygulanarak işletmelerin maliyet performansı ölçümü yapılmıştır.

\section{LITERATÜR İNCELEMESİ}

Yerli ve yabancı literatürde Tekstil, Giyim Eşyası ve Deri sektöründe faaliyet gösteren işletmeler hakkında birçok çalışma bulunmaktadır. Yapılan çalışmalarda VZA, Stoastik Sınır Analizi, Açıklanmış Karşılaştırmalı Üstünlükler (AKÜ) Analizi, Çok Boyutlu Regresyon Analizi, Malmquist Toplam Faktör Verimlilik Endeksi, Analitik Hiyerarşi Süreci (AHS) ve TOPSIS gibi teknikler kullanılmaktadır. Araştırmacılar çalışmalarında bu tekniklerden sadece birini kullanabildikleri gibi, iki ve daha fazla tekniğin de birlikte kullanıldığı çalışmalar yapılmaktadır. Bu bölümde, ulusal ve uluslararası literatürdeki tekstil, hazır giyim ve deri işletmelerinin etkinlikleri üzerine yapılan çalışmalara yer verilmektedir. 
Chandra, Cooper, Li ve Rahman (1998), VZA kullanılarak Kanadalı 29 tekstil şirketinin performans analizini değerlendirdikleri çalışmalarında CCR modelini kullanmışlardır. Verimsiz girdilerin azaltılması ile azaltılmaması arasındaki dengeyi değerlendirmek için matematiksel bir model geliştirmişlerdir. Araştırma kapsamındaki şirketlerin, strateji ve kapasite planlarında değişiklik yapıp, performanslarını yenilemeleri gerektiği sonucuna varmışlardır.

Kayalıdere ve Kargın (2004), tarafından yapılan çalışmada, BIST'te işlem gören tekstil ve çimento sektörlerine ait şirketlerin 2002 yılı etkinlikleri VZA ile ölçülmüş ve etkin olmayan şirketlerin etkin ve verimli duruma geçmeleri için etkin şirketler baz alınarak hangi oranda iyileşme yapılması gerektiği araştırılmıştır. Çimento sektörü için 15 firma, tekstil sektörü için 27 firmanın verileri kullanılmıştır. Birinci analizde, girdi olarak; personel sayısı ve toplam aktif değerler, çıktı olarak; net satış ve net kâr değerleri kullanılmıştır, ikinci analizde ise girdi olarak personel sayısı ve maddi duran varlıklar kullanılmış, çıktı olarak net satış ve net kâr kullanılmıştır. Çimento sektöründe 3 şirket etkin bulunurken, 12 şirketin etkin sınıra ulaşamadıkları tespit edilmiştir. Yapılan ikinci analizde etkin bulunan şirket sayısı 4'e çıkmıştır. Tekstil firmaları değerlendirildiğinde iki analizde de 5 şirket etkin bulunmuş ama etkin bulunan şirketlerin 1 tanesi farklılaşmıştır. Sonuç olarak girdi ve çıktı ağırlık değerlerine karşı hassas bir analiz çeşidi olduğu için verilerin doğru seçilmesi gerekmektedir. Çünkü sonuçların farklılaşmasına neden olmaktadır.

Çetin (2006), tarafından yapılan çalışmada, BIST'te yer alan tekstil ve hazır giyim sektörü 2004/12 y1lı baz alınarak girdi değişkeni olarak cari oran, likidite oranı, nakit oranı, net işletme sermayesi/toplam aktifler kullanılırken, çıktı olarak öz sermaye kâr marjı, aktifler kâr marjı, net kâr marjı kullanılmıştır. Kurulan modellerin çözümünde ise LINNO paket programından yararlanılmıştır. Analiz sonucunda 22 firmadan 4 tanesinin göreli olarak tam etkin olduğunu tespit edilmiştir.

Perçin ve Ustasüleyman (2007), tarafından yapılan çalışmada VZA ve Malmquist toplam faktör verimliliği endeksi yaklaşımları kullanılarak 2000 ve 2002 döneminde BIST ulusal pazarda yer alan dokuma, giyim eşyası ve deri ile gıda içki ve tütün firmalarının etkinlikleri ölçülmüştür. Göreli etkinlikleri ölçüldükten sonra etkin sınırdan uzaklaşmaya neden olan faktörler duyarlılık analizi ile araştırılmıştır. TFP 
(total factor productivity) endeksi ile etkinlik ve verimlilik bileşenlerindeki değişmeler incelenmiştir. Gıda sektöründe 24, tekstil sektöründe 31 işletme incelenmiştir. Girdi olarak firmaların çalışan sayısı, aktif toplamı ve öz sermaye tutarı seçilmiştir. Çıktı olarak; satışlar, kâr, piyasa değeri, hisse başına getiri ve hisse başına kâr kalemleri kullanılmıştır. Tekstil firmalarının ÖGSG'ye göre 12'si, ÖGDG'ye göre 17'si etkin bulunurken; g1da sektöründe ÖGSG'ye göre 16, ÖGDG'ye göre 19'u etkin bulunmuştur.

Sarıçam ve Erdumlu (2012), 2003-2008 döneminde BIST'te yer alan tekstil, konfeksiyon ve deri sektöründe yer alan şirketlere BCC modelini uygulamıştır. BIST'te yer alan hazır giyim sektöründe 10, tekstil sektöründe 23 firma değerlendirilmiştir. Girdi olarak net aktifler ve çalışan sayısı; çıktı olarak vergi öncesi kâr, ihracat geliri, brüt katma değer kullanılmıştır. Sonuç olarak yapılan analiz, tekstil ve konfeksiyon endüstrisi arasında sektöre özgü tuzakların tespit edilebilmesine ve sektörlerin performanslarını karşılaştırarak inceleme yapılabilmesine imkân vermiştir.

Demir (2013), tarafından yazılan yüksek lisans tezinde 2003-2010 yılları arası Türk Tekstil Sektörü'nün performans analizi incelenmiştir. Araştırmada toplam mal ve hizmet alışları, ücretli çalışanların çalıştıkları saat sayısı ve girişim sayısı girdi olarak alınırken üretim değeri çıktı olarak alınmıştır. Tekstil sektörünün üretim performans1, küresel ekonomik dinamiklerden etkilenmektedir. Bunun yanında teknolojinin payı da oldukça fazladır. Son zamanlarda ürün bazında tekstil makineleri ve ekipmanı azalmış, dışa bağımlı konuma gelmişlerdir. Araştırmada, Türk Tekstil Sektörü'nün teknolojik alandaki yatırımlarını arttırması gerektiği sonucuna varılmıştır.

Öztürk (2014), Türk tekstil ve hazır giyim sektöründe faaliyet gösteren firmaların 2012 yılı ihracat etkinliklerini VZA ve AHS yöntemleriyle değerlendirmek amacıyla yazdığı yüksek lisans tezi ile İstanbul Sanayi Odası (İSO) 500'e giren tekstil firmalarının 2012 yılı verilerinin ihracat etkinlikleri üzerinde inceleme yapmıştır. Etkinlik düzeylerinin belirlenmesi için girdi olarak çalışan sayısı, aktif toplamı, ihracat yapılan ülke sayısı, ihracat tecrübesi kullanılmış ve çıktı olarak ihracat satış tutarı değişkeni kullanılmıştır. Analiz sonucunda dört firma etkin bulunmuştur. İhracat performansında en önemli kriter ürün politikalarıdır. İhracat performansı açısından 
en çok öneme sahip olan kriterleri; ürün politikası, fiyatlandırma politikası, yönetsel politikalar, ihracat tecrübesi ve teknolojik altyapıdır. Buna karşılık, en az öneme sahip kriterlerin ise dağıtım politikası ve sahiplik durumu olduğu sonucuna ulaşılmıştır.

Usman vd. (2014), Pakistan'da 100 tekstil firmasının 2006-2011 yılları arasını kapsayan dönemde verimlilik ve performanslarını ölçmüştür. VZA'da sabit ölçek modeli ve değişken ölçek modeli getirileri; 0,82 ve 0,86 değerlerinin bulunması, Pakistan tekstil sektörünün verimliliğe yakın olduğunu ortaya koymuştur. Firma yaşı, pazar payı ve satış artışı olumlu etkilenirken; firma büyüklüğü, ihracat katılımı ve finansal kaldıraç oranları Pakistan'ın tekstil sektörünün performansı üzerinde olumsuz etkileri olduğu tespit edilmiştir.

Verma, Kumavat ve Biswas (2015), tarafından yapılan bir çalışmada, Hindistan' da seçilmiş 10 tekstil fabrikası için numunenin teknik verimliliği VZA ile ölçülmüştür. 2012 ve 2013 yılları verileri kullanılmıştır. CCR modeli kullanılmış ve girdi olarak ham madde maliyeti (yün, sentetik, polimer vb.) - yakıt ve enerji maliyeti (fuel oil, lpg, elektrik vb.) - çalışanların maliyetini (işçi maaşı vb.) kullanılırken, çıktı olarak satışlar (ürünlerin maliyeti) ve net kârlılık oranı kullanılmıştır. Araştırmada, verimsiz rafinerilerde kaynak kullanımının azaltılması, daha iyi performans sağlamak için kaynakların boşa harcanmaması ve tam faydalanılması gerektiği sonucuna ulaşılmıştır.

Özçelik ve Kandemir (2017)'in makalesinde BIST'te işlem gören imalat sektöründe yer alan işletmelerin VZA ile etkinlik ölçümü yapılmıştır. 2012 ile 2014 yılları arasına ait yıllık bilanço ve gelir tabloları ile finansal oranları hesaplanmıştır. Girdi olarak; cari oran, likidite oran ve stok devir hızı kullanılmış, çıktı verileri için; net kâr marjı, öz sermaye kârlılığı ve aktif kârlılık oranları kullanılmıştır. VZA sonucunda imalat sektöründe kalıcı olabilmek için işletmeler kaynaklarını etkin kullanmalı ve eksiklerini tamamlamalıdır. İşletmeler etkinlik değerlendirmesi yaparak geçmişten günümüze durumlarını değerlendirip, gelecek dönemlerdeki hedeflerine göre planlarını şekillendirebileceklerdir.

Akın (2018), BIST'te kayıtlı dokuma sektöründe faaliyet gösteren 17 firmanın 2013 ve 2017 yıllarına ait verilerini analiz etmiştir. VZA'da girdi esaslı CCR modeli uygulanmış ve firmaların etkinlik değerlerindeki değişimi analiz etmek için 
Malmquist toplam faktör verimlilik endeksi uygulanarak firmaların etkinlik analizi yapılmıştır. Analizlerde cari oran, asit-test oranı, kaldıraç oranı, finansman oranı, stok devir hızı ve aktif devir hızı girdi değişkeni olarak yer alırken, toplam aktif kârlılığı ve satışların kârlılığı olmak üzere iki adet çıktı değişkeni kullanılmıştır. Çalışma sonucunda 2013 yılında 8 firmanın, 2014 yılında 6 firmanın, 2015 yılında 4 firmanın, 2016 ve 2017 yıllarında ise 5 firmanın göreli olarak \%100 etkinliğe sahip olduğu tespit edilmiştir.

Özçelik ve Avcı Öztürk (2019), BIST’e kayıtlı 2015 ve 2017 yıllarının gıda, içecek işletmelerinin maliyet yönetimindeki göreli etkinliklerini $\mathrm{VZA}^{\prime}$ da girdi esaslı CCR ve BCC modellerini kullanarak analiz etmiştir. İşletmelerin maliyet verilerine ilişkin oranları (satışların maliyeti/satış hasılatı, yönetim gideri/satış hasılatı, pazarlama gideri/satış hasılatı) girdi değişkeni, kârlılık oranları da (aktif kârlılı̆̆ı, öz kaynak kârlılığı, net kâr marjı, faaliyet kâr marjı) çıktı değişkeni olarak kullanılmıştır. Ölçeğe göre sabit ve değişken getiri varsayımı altında toplamda 22 adet işletmenin 4 tanesi rakip firmalara kıyasla etkin bir performans göstermiştir.

\section{PERFORMANS ÖLÇME YÖNTEMLERI}

İşletmelerde çalışanların performansları sistematik olarak değerlendirilmesi 1900'lü yılların başında ABD’de kamu hizmeti sunan kurumlarda görülmektedir. Taylor'un iş ölçümü uygulamaları ile çalışanların verimlilikleri ölçümlenmiş sonrasında ise performans değerlendirme kavram olarak işletmelerde kullanılmıştır (Uyargil, 2014, s.3).

Performans; bireyin, topluluğun, örgütün ya da bir işletmenin yaptığ1 işle, hedeflediği iş arasındaki yapabilme düzeyi ya da hangi noktaya kadar gelebileceğinin say1sal veya sözel ifadesidir (Kecek, 2010, s.11). Performans ölçümü ise; işletmelerin kullandığı kaynakların, ürettiği mal ve hizmetlerin, ulaştıkları sonuçların takip edilmesi için sistemli ve düzenli bir şekilde veri toplanması, toplanan verilerin analiz edilmesi ve raporlanması şeklinde tanımlanır (Sayıştay, 2003, s.9). Performans ölçümü, işletmelerin kullandığı programları, sistemleri, tasarladığı işleri ve süreçleri ölçtüğü ve izlediği yapılandırılmış bir süreçtir. Endüstri, hizmet ve ticaret işletmeleri fark etmeksizin, her sektörde performans ölçümü çok önemlidir. İşletmelerin hedefleri doğrultusunda yapılan işlerde kaynakların verimli ve doğru kullanılması gerekir. 
Çünkü kurumların performansı, verimlilik ile ilişkilidir. Performans ölçümünün verimli olması için kaynakların verimli kullanılması, kalitenin arttırılması, müşteri memnuniyetinin sağlanması ve stratejik hedeflerin gerçekleştirilmesi gerekir (Alrashidi, 2015, s.11-12).

Performans ölçütleri, basit, anlaşılması kolay ve günlük işlerle ilgili olmalıdır. Ölçmek istenilen amaca uygun ve kullanıcının ihtiyacı doğrultusunda kriterler belirlenmelidir. Eksik bırakılan veya birbiriyle çakışan kriterler olmamalıdır. Ölçülmesi planlanan konu üzerinde, fikir birliğine varılmalıdır. Kullanılan verilerin sayısal bilgiler içermesi, kriterlerin değişen ihtiyaca uyarlanabilmesi yani esnek olması gerekmektedir (Erin, 2010, s.7-8).

Muhasebe verilerine dayalı performans ölçütleri, belirli bir dönemde ortaya çıkan faaliyet sonucunu esas almaktadır. Bu performans ölçüleri, muhasebe faaliyetleri sonucunda meydana gelen kâr rakamının hesaplanmak istendiği değere bölünmesi sonucu ortaya çıkarlar. Finansal tablolarda bulunan kâr rakamı, risk parametresini dikkate almamaktadır. Finansal tablodaki kârın, hangi riskler çerçevesinde ortaya çıktığı bilinmemektedir. Muhasebe esaslı finansal performans göstergeleri; öz kaynak kârlılığı, varlık (aktif) kârlılığı, yatırılan sermayenin getirisi ve hisse başı kârdır (Şenol ve Ulutaş, 2018, s.86).

\subsection{Etkinlik- Etkililik- Verimlilik}

Etkinlik mevcut kaynakların kullanımı ile ilgili bir kavramdır yani girdi miktarını arttırmadan, çıktı düzeyini maksimum hale getirmektir. Etkililik; planlanan miktar, belirlenen hedef ve amaçların gerçekte ne kadarına ulaşıldığı ile ilgilidir (Demir, 2013, s.50). Bu iki kavramın merkezinde yer alan verimlilik ise kisitlı kaynaklarla kaliteyi arttırmak şeklinde açıklanmaktadır. Ayrıca yüksek performans için yüksek etkinlik değeri şarttır (Yürüşen, 2011, s.6).

Verimlilik bakış açısına ya da kullanılan içeriğe göre değişiklik göstermektedir. Yapılan işte ne kadar iyi olduğumuz anlamına gelir. Ürün ve hizmetlerin ne kadar etkin olduğu ile alakalı durumdur. Doğru işler yaparak istenen sonuçları elde etmek için kaynakları doğru kullanmaktır. Girdi faktörü (yani insan ya da fiziksel kaynaklar) ile üretilen çıtı (ürün ya da hizmet) arasındaki ilişkidir (Pekuri, Haapasalo ve Herrala, 
2011, s.41). Yüksek verimlilik ise belirli miktarda olan kaynakla daha çok üretmek yani daha fazla çıktı elde etmektir (Prokopenko, 2011, s.19).

Etkinlik kavramı iktisat biliminde en az çaba ya da maliyet ile maksimum seviyede sonuç verme kapasitesi, organizasyonel alanda ise girdi çıktının en uygun şekilde yapılması şeklinde tanımlanmıştır (Bakırcı, 2006, s.201). Etkinlik oranı bulunurken 1 değeri elde edilmeye çalış1lır. Eğer bulunan değer 1'in altındaysa faaliyetlerin istenildiği gibi sonuçlanmadığı, 1 değerini aşması durumunda ise hedefin üstünde performans gösterildiği anlaşılır (Yürüşen, 2011, s.6).

\subsection{Etkinlik Ölçme Yöntemleri}

Yönetim muhasebesinde performansa dayalı analiz yapılmaktadır. Bunun için kullanılan üç farklı teknik; oran analizi, parametrik analiz ve parametrik olmayan analiz teknikleridir.

Oran analizi: Performans ölçerken en çok tercih edilen analiz çeşidi oran analizidir. Girdi ve çıktı sayısının tek olması kullanım kolaylığı sağlamaktadır. Tek girdi ve tek çıktı kullanılması etkinlik ölçümünde bir boyutu ele aldığı için, alınmayan diğer boyutlar göz ardı edilmektedir. Oran analizinin diğer bir dezavantajı mutlaka karşılaştırma yapmaya ihtiyaç duymasıdır. Çıkan sonuçlar ya kendi dönemleriyle ya da yıllar bazında diğer çıkan sonuçlarla karşılaştırılması sonucunda anlamlı olacaktır. Oran analizinde çıkan sonuçlar işletmeyi bazen etkin, bazen de başarısız gösterebilmektedir. Tekli oran yerine genişletilmiş oranlar kullanıldığı takdirde, daha doğru sonuçlara ulaşılacaktır. Bu yüzden etkinlik ölçümünde farklı oranları anlamlı biçimde ağırlandırılarak, tek ölçüt kullanılmasına ihtiyaç duyulmaktadır (Oruç, 2008, s.7).

Parametrik yöntemler: Parametrik yöntemlerin kullanılabilmesi için faaliyet sonuçlarının tek değişkenle tanımlanması gerekmektedir. Bağımlı değişken tek bir değişkenden oluşmuyorsa, parametrik yöntem kullanmak organizasyonun etkinliğini sonuca ulaştırmayacaktır. Faaliyet sonuçlarının değerlendirilmesinde, parametrik yaklaşım kullanıldığında bazı yetersizlikler karşımıza çıkmaktadır. Parametrik yöntemler tek çıktı kullanımına izin verdiği için, kamu sektörü gibi bazı alanlarda sonuç elde edilemeyecektir. Kamu sektöründe, harcama programları veya kamu 
politikaları çok sayıda sonuç elde etmeyi planladığı için yetersiz kalacaktır. Parametrik yöntemler ortalama değere göre yapıldığı için, en iyi performansı sağlayan karar birimine bağlı olmayacaktır. Ayrıca parametrik yöntemlerle bulunan ortalama üretim fonksiyonu, grubun içindeki çeşitliliği gözlemleyememektedir. Tahmin edilen fonksiyonun katsayıları sabit olduğu için, karar birimlerinin benzer üretim yaptığı varsayılır. Bu yüzden değişik üretim teknolojilerini dişlamaktadır (Güran ve Tosun, 2005, s.94-95).

Parametrik olmayan yöntemler, doğrusal programlama tabanlı teknikler kullanılarak, etkinlik sınırına olan uzaklığı tespit etmek için kullanılır. Üretim biriminin yapısı ile alakalı davranışsal öngörü kullanmak zorunda olmadıkları için avantaj sağlar. Parametrik yöntemin aksine etkinlik ölçümünde birden fazla girdi ve çıktı değişken kullanılabilmesi ekstra avantaj sağlamaktadır. Buna rağmen rassal hata terimi içermediği için tesadüfi veya diğer sebeplerle oluşan hataların modele aktarılması etkinlik sınırının yanlış tespit edilmesine neden olur. Parametrik olmayan yöntemlerin en sık kullanılanı 1978 yılında Charnes, Cooper ve Rhodes'un geliştirdiği VZA tekniğidir (Seyrek ve Ata, 2010, s.69).

\subsection{Analiz Yöntemi Olarak Veri Zarflama Analizi}

Doğrusal programlama temeline dayanan ve etkinlik ölçümünde kullanılan VZA, Farrel'in 1957'de performans etkinliğini belirlemek için yaptığ1 teorik çalışmadan yola çıkarak Charnes, Cooper ve Rhodes tarafından geliştirilen parametrik olmayan istatistiksel karşılaştırma tekniğidir. CCR (Charnes, Cooper, Rhodes) yaklaşımı olarak bilinen bu çalışma, yöneylem araştırması ve idari bilimler çevrelerinden başlayıp ekonomi alanına da yayılarak, veri zarflama adı altında popüler bir yaklaşım haline gelmiştir (Behdioğlu ve Özcan, 2009, s.303). Ayrıca VZA'ya 1978 yılında kamu sektöründe kâr amacı gütmeyen firmalarda, verimliliği ölçmek amacıyla 'Karar Verme Birimlerinin Etkinliğini Ölçme' adlı makalede yer verilmiştir (Javid, 2018, s.13).

VZA verimlilik için regresyon analizine alternatif olarak ortaya çıkmıştır. VZA yönteminin en büyük avantajlarından biri aynı analizde birden fazla girdi ve çıktıları işleme imkânı sağlamasıdır. VZA analistler için, hızlı ve kolay performans ölçümü 
elde edilmesini sağlayan bir yöntemdir. Birden fazla girdi ve çıktı değerini tek bir verimlilik değerine dönüştürmektedir. Sonuçların yorumlanmasıyla bireysel önerilerde bulunulup, ekonomik önlemler almaları için karar vericilere fayda sağlamaktadır (Frehe, 2013).

VZA orijinal sabit ölçek (CCR) modeline dayanır. Uygulaması esas olarak kâr amacı gütmeyen kuruluşların verimlilik değerlendirilmesine odaklanmıştır. Çünkü bu kuruluşlar ticari şirketler için kullanılan geleneksel ekonomik ve finansal göstergeler temelinde değerlendirilmez. VZA terimi ilk kez ABD'de Rhodes tarafından 1978 yılında program takip analizinde kullanılmıştır. O zamandan sonra etkinlik analizi; güvenlik, ilçe hapishaneleri, mahkemeler, üniversiteler, madencilik, hava taşımacılığı hatta bankacılık alanlarında kullanıldı. Analiz yapılırken değerlendirilecek birimler homojen olmalı ve karşılaştırmaya dayanarak değerlendirilmelidir (Jorge, Negas \& Santos, 2013, s.38).

Son zamanlarda birçok uygulamaya konu olan VZA birçok farklı performansın değerlendirilmesinde kullanılmıştır. VZA'da kullanılan metodoloji daha az bilinen teorilerden ziyade temel olarak lineer cebire (matrisler ve vektörler dahil) dayanmaktadır ve kullanım avantajı ise formülasyonların çok doğal ve kolay bir şekilde birbiriyle temas kurmasıdır (Cooper, Seiford \& Tone, 2000, s.22).

\subsubsection{VZA'da Kullanılan Yöntemler}

VZA'da pek çok model kullanılmaktadır. Bu modeller aşağıda sıralanmıştır.

- CCR Modeli / Ölçeğe Göre Sabit Getiri (ÖGSG) Modeli

- BCC Modeli /Ölçeğe Göre Değişken Getiri (ÖGDG) Modeli

- Toplamsal Model (Additive Model)

- Ölçeğe Göre Azalan Getiri Modeli

- Ölçeğe Göre Artan Getiri Modeli

- Aylak Tabanlı Ölçüm Modeli

- Süper Aylak Tabanlı Model'dir.

\subsubsection{Charnes-Cooper-Rhodes (CCR) Modeli}

Bu model, toplam etkinliği ÖGSG varsayımı altında ölçmektedir (Kecek, 2010, 
s.66). VZA'dan girdi ve çıktı yönelimli iki şekilde faydalanılabilmektedir. Girdi üzerinde kontrol az ise çıktı yönelimli, çıktı üzerinde kontrol az ise girdi yönelimli model oluşturulmalıdır (Özden, 2008, s.170).

Tablo 1. Girdi ve Çıktı Esaslı CCR Modeli

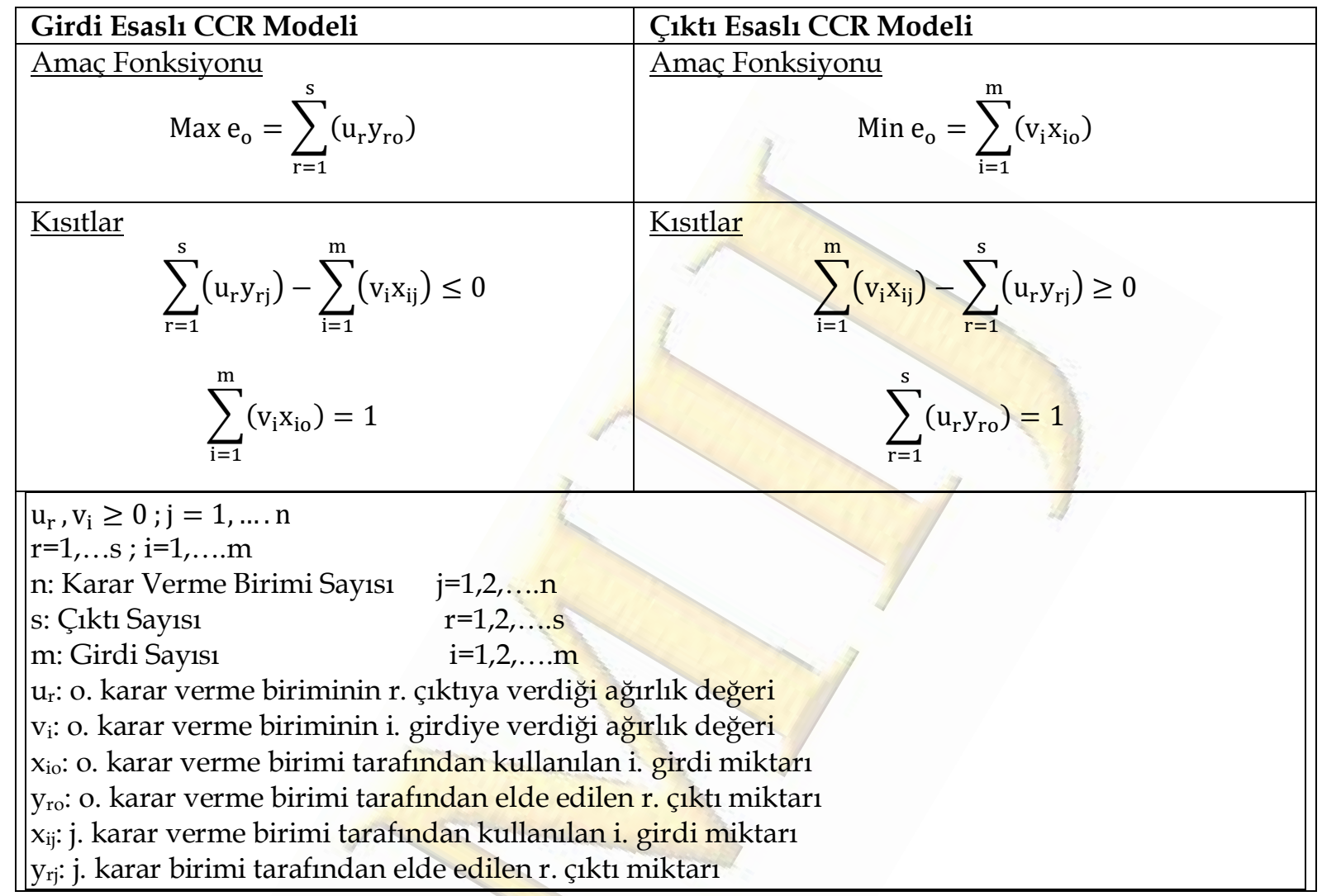

Kaynak: Kiran, 2008, s.25.

\subsubsection{Banker-Charnes-Cooper (BCC) Modeli}

BCC modeli, Banker, Charnes ve Cooper tarafindan 1984 yılında CCR modelinin geliştirilmesiyle ÖGDG varsayımı altında etkinliği ölçmek için oluşturulmuştur. CCR ve BCC modellerinde etkinlik sınırı farklı görüntü vermektedir. ÖGSG varsayımından dolayı tek girdi ve tek çıktı durumu için etkinlik sınırı CCR modelinde orijinden geçen bir doğru şeklindeyken, BCC modelinde parçalı doğrusal ve iç bükey şeklinde oluşmaktadır. BCC modelinin geçerli bölgesi, CCR modelinin geçerli bölgesinin alt kümesi olduğundan bir karar verme birimi CCR modeli ile etkin bulunmuşsa, BCC modeli ile de etkin bulunacaktır (Demir, 2013, s.72). 
Tablo 2. Girdi ve Çıktı Esaslı BCC Modeli

\begin{tabular}{|c|c|}
\hline Girdi Esaslı BCC Modeli & Çıktı Esaslı BCC Modeli \\
\hline $\begin{array}{r}\underline{\text { Amaç Fonksiyonu }} \\
\operatorname{Max~}_{\mathrm{o}}=\sum_{\mathrm{r}=1}^{\mathrm{s}}\left(\mathrm{u}_{\mathrm{r}} \mathrm{y}_{\mathrm{ro}}\right)+\mathrm{u}_{\mathrm{o}}\end{array}$ & $\begin{array}{l}\text { Amaç Fonksiyonu } \\
\text { Min } \mathrm{e}_{\mathrm{o}}\end{array}=\sum_{\mathrm{i}=1}^{\mathrm{m}}\left(\mathrm{v}_{\mathrm{i}} \mathrm{x}_{\mathrm{io}}\right)-\mathrm{v}_{\mathrm{o}}$ \\
\hline $\begin{array}{c}\text { Kisitlar } \\
\sum_{\mathrm{r}=1}^{\mathrm{s}}\left(\mathrm{u}_{\mathrm{r}} \mathrm{y}_{\mathrm{rj}}\right)-\sum_{\mathrm{i}=1}^{\mathrm{m}}\left(\mathrm{v}_{\mathrm{i}} \mathrm{x}_{\mathrm{ij}}\right)+\mathrm{u}_{\mathrm{o}} \\
\sum_{\mathrm{i}=1}^{\mathrm{m}}\left(\mathrm{v}_{\mathrm{i}} \mathrm{x}_{\mathrm{io}}\right)=1\end{array}$ & $\begin{array}{l}\left.\mathrm{r}_{\mathrm{rj}}\right)-\mathrm{v}_{\mathrm{o}} \geq 0 \\
\mathrm{f}=1\end{array}$ \\
\hline 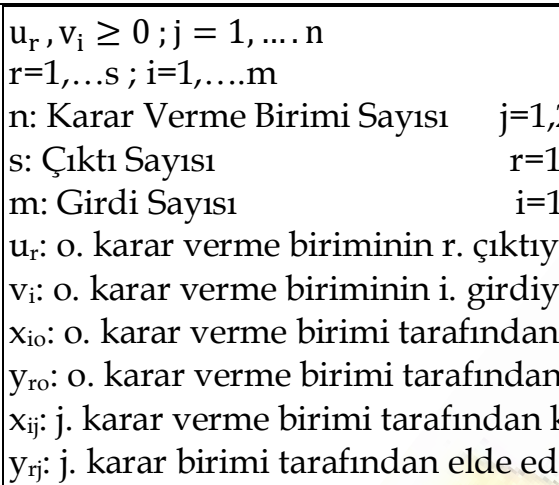 & $\begin{array}{l}\text { Irlik değeri } \\
\text { arlı değeri } \\
\text { girdi miktarı } \\
\text { r. çıtı miktarı } \\
\text { girdi miktarı } \\
\text { niktarı }\end{array}$ \\
\hline
\end{tabular}

Kaynak: Kiran, 2008, s.27-28

\subsubsection{Toplamsal (Additive) Model}

Toplamsal model, 1985 yılında Charnes, Cooper, Golany, Seiford ve Stutz tarafından geliştirilmiştir. CCR ve BCC modelleri girdi ve çıktı esaslı olarak ayrı ayrı değerlendirme yapmaktadırlar. Bu model ise girdi ve/veya çıtıya yönlendirilmeden sonuç üretmektedir. ÖGDG varsayımı altında çalışır. Toplamsal modelin çözüm alanı dış bükey bir yapı oluşturmaktadır. Bu model konik zarf şekli oluşturan ÖGSG durumuna göre daha sıkı dış bükeylik oluşturarak veri noktalarını daha sıkı sarar (Yavuz ve İşçi, 2013, s.162).

Toplamsal modelde asıl amaç girdi fazlası ve çıktı eksikliğini birlikte değerlendirip, etkinlik sınırı üzerinde etkinsiz olan karar birimine en uzak noktayı hesaplamaktır. Bu model sonucu, etkinlik değeri elde edilmemektedir. ÖGDG varsayımına dayanan bu model, veri zarflamayı Charnes-Cooper'ın etkin olmama analizi ile ilişkilendirmektedir (Kıran, 2008, s.29). 


\subsubsection{Veri Zarflama Analizinde İzlenecek Adımlar}

VZA'da izlenecek adımlar; karar verme birimlerinin seçilmesi, girdi ve çıktıların seçilmesi, modelin seçilmesi, göreli etkinliğin ölçülmesi ve sonuçların değerlendirilmesi olmak üzere beş aşamalıdır.

1. Karar Verme Birimlerinin Seçimi: Karar verme birimleri, girdilerin çıtılara dönüştürülmesini sağlayan herhangi bir ekonomik birim olabilir (Kecek, 2010, s.78). VZA için öncelikle benzer kararların uygulandığı ve benzer organizasyonların olduğu karar birimlerinin seçilmesi gerekir (Dinçer, 2008, s.829).

2. Girdi ve Çıktıların Seçimi: VZA tekniği veri tabanlı etkinlik ölçümü yaptığı için girdi ve çıktıların seçimi aşaması analizin temelini oluşturmaktadır. Karar verme birimlerine göre süreci en iyi ifade edecek girdi ve çıtıların belirlenmesi gerekmektedir. Girdi ve çıktı birimlerinin sayısı arttırılmak istendiğinde, karar verme birimlerinin sayısının da arttırılması gerektiği unutulmamalıdır (Budak, 2010, s.98).

3. Modelin Seçimi: Hangi modelin seçilmesi konusu girdi ve çıtı değişkenlerine bağlıdır. Girdi üstünde kontrol azsa çıktı odaklı, eğer çıktı üzerinde kontrol az ise girdi odaklı modelin kullanılması gerekir (Demir, 2013, s.64). Girdi odaklı modeller, belirli çıktı düzeyini sağlamak için etkin olmayan karar birimlerinin girdilerini ne kadar azaltması gerektiğini belirlerken, çıktı odaklı modeller ise verilen bir girdi bileşimi ile etkin olmayan karar birimlerinin etkinliğinin sağlanması için çıktıların ne kadar arttırılması gerektiğini belirlemeye çalışan modellerdir (Akyüz, Yildirım ve Balaban, 2015, s.29).

4. Göreli Etkinliğin Ölçümü: Göreli etkinliğin ölçümü için, karar biriminin her biri için 0 ile 1 arasında değer hesaplanır. Eğer çıkan sonuç 1 ise o birim etkin kabul edilir. Etkinlik sınırı oluşturulur (Kecek, 2010, s.80). Çıkan sonuç 1'den küçükse göreli etkinsizdir. Ayrıca etkinlik değerleri etkinlik sınırına olan uzaklığı belirtir (Behdioğlu ve Özcan, 2009, s.304).

5. Sonuçlarnn Değerlendirilmesi: Göreli etkinlik ölçüldükten sonra, gözlem kümesinin etkin ve etkin olmayan karar verme birimleri için elde edilen sonuçlar değerlendirilir. Değerlendirme yapılırken bütün girdi ve çıktılar dikkate alınır. Etkin ve etkin olmayan karar verme birimleri için VZA yardımıyla karar verici belirlediği 
amaçlara ulaşıp ulaşmadığını tespit ederken, işletme için iyileştirme yapması gereken konuları da belirleyecektir.

\subsubsection{VZA İçin Kullanılan Paket Programlar}

VZA'nın temeli doğrusal programlamaya dayandığı için bu analizde doğrusal programlama çözümlerinde kullanılan LINDO, GAMS, QSB, STORM gibi programlar kullanılabildiği gibi EMS, IDEAS, DEAP, ETAKS, Warwick Windows DEA, PIONEER gibi Windows altında çalışan programlar da kullanılmaktadır. DEAP 2.1 ulaşılabilirliği, kolay ve ücretsiz olması açısından en çok tercih edilen, birçok analize izin veren, verimli çalışan bir yazılımdır. DEAP 2.1 yazılımı, 431 ekonomik karar birimi için bir saniye gibi kısa bir sürede çözümlenebilmektedir (Özden, Özer ve Çınar, 2012, s.772).

\section{BIST TEKSTILL SEKTÖRÜNDE UYGULAMA}

VZA uygulamasına başlamak için öncelikle aynı kararların uygulandığı, benzer örgütsel yapıya sahip karar verme birimlerinin belirlenmesi gerekmektedir. İnsan yaşantısının temel gereksinimi olan giyinme ihtiyacı, tekstil, giyim eşyası ve deri sektörünü önemli kılmaktadır. Geçmişten günümüze tekstil, giyim eşyası ve deri sektörü gerek iç piyasada gerekse ihracat alanında ülke ekonomisinde önemli yere sahiptir. Tekstil, giyim eşyası ve deri sektöründeki işletmelerin fazla olması ayrıca rekabet ve teknoloji artışı karşısında bu alanı incelemek cazip hale gelmektedir.

Bu çalışmada karar verme birimi olarak 2017-2019 yılları arasında BIST'e kote olan imalat sektörü altında yer alan tekstil, giyim eşyası ve deri bölümünde işlem gören 19 adet firmanın VZA ile BCC ölçekte girdi yönlü etkinlikleri DEAP 2.1 programında ölçülmektedir. Tablo 3'te araştırma kapsamında yer alan işletmeler verilmiştir. 
Tablo 3. 2017-2019 Yılları Arasında BIST Tekstil, Giyim Eşyası ve Deri Endeksinde Yer Alan İşletmeler

\begin{tabular}{|c|c|c|}
\hline \multicolumn{3}{|c|}{ TEKSTILL, GIIYIM EŞYASI VE DERİ } \\
\hline Sira & Kod & Şirket Unvanı \\
\hline 1 & ATEKS & AKIN TEKSTİL A.Ş. \\
\hline 2 & ARSAN & ARSAN TEKSTIL TICARET VE SANAYİ A.Ş. \\
\hline 3 & BLCYT & BİLICİ YATIRIM SANAYİ VE TİCARET A.Ş. \\
\hline 4 & BRKO & BİRKO BİRLEŞİK KOYUNLULULAR MENSUCAT TİC. VE SAN. A.Ş. \\
\hline 5 & BRMEN & BİRLIKK MENSUCAT TİCARET VE SANAYİ İSELTMESİ A.Ş. \\
\hline 6 & BOSSA & BOSSA TICARET VE SANAYİ İŞLETMELERİ T.A.Ş. \\
\hline 7 & DAGI & DAGİ GIYYIM SANAYİ VE TİCARET A.Ş. \\
\hline 8 & DERIM & DERIMOD KONFEKSIYYON AYAKKABI DERİ SAN. VE TİC. A.Ş. \\
\hline 9 & DESA & DESA DERİ SANAYİ VE TİCARET A.Ş. \\
\hline 10 & HATEK & HATEKS HATAY TEKSTİL İŞLETMELERİ A.Ş. \\
\hline 11 & KRTEK & KARSU TEKSTILL SANAYİI VE TİCARET A.Ş. \\
\hline 12 & KORDS & KORDSA TEKNIK TEKSTIL A.Ş. \\
\hline 13 & LUKSK & LÜKS KADİFE TİCARET VE SANAYİI A.Ş. \\
\hline 14 & MNDRS & MENDERES TEKSTIL SANAYİ VE TİCARET A.Ş. \\
\hline 15 & RODRG & RODRIGGO TEKSTIL SANAYİ VE TİCARET A.Ş. \\
\hline 16 & SKTAS & SÖKTAŞ TEKSTIL SANAYİ VE TİCARET A.Ş. \\
\hline 17 & SNPAM & SÖNMEZ PAMUKLU SANAYİI A.Ş. \\
\hline 18 & YATAS & YATAŞ YATAK VE YORGAN SANAYİ VE TICARET A.Ş. \\
\hline 19 & YUNSA & YÜNSA YÜNLÜ SANAYİ VE TİCARET A.Ş. \\
\hline
\end{tabular}

VZA'nın ikinci aşaması olan girdi ve çıtı değişkenlerinin belirlenmesi analizin yapılma amacı açısından oldukça önemli yere sahiptir. Girdi olarak kullanılan gider kalemlerini etkin kullanmak ve girdi oranlarında iyileştirme yaparak göreli etkinliğe ulaşmak istenmektedir. Analizde üç girdiye karşılık iki çıktı kullanılmıştır. Faaliyet giderlerinden pazarlama gideri ve yönetim giderinin satış hasılatına oranı ve satışların maliyetinin satış hasılatına oranı girdi olarak kullanılırken, aktif kârlılığı ve öz kaynak kârlılığı çıktı faktörü olarak kullanılmıştır. Tablo 4'te işletmelerin analizde kullanılan girdi ve çıktı değişkenleri verilmiştir.

Tablo 4. Girdi ve Çıktı Değişkenleri

\begin{tabular}{lll}
\hline No & Girdiler & Çıtılır \\
\hline 1 & Satı̧̧ların Maliyeti / Satı̧lar & Öz Sermaye Kârlılığı: Net Kâr / Öz Kaynaklar \\
2 & Genel Yönetim Giderleri / Satışlar & Aktif Kârlılık Oranı: Net Kâr / Toplam Varlıklar \\
3 & $\begin{array}{l}\text { Pazarlama, Satış ve Dağıtım Giderleri / } \\
\text { Satı̧lar }\end{array}$ & \\
\hline
\end{tabular}


VZA'da, çıktı kümesinin elemanlarında negatif değerlerin olması, yöntemin değişkenlere ilişkin pozitif değer alma varsayımına uymadığı için bu değerler verilen normalizasyon formülü ile pozitif hale getirilmelidir (Özçelik ve Avcı Öztürk, 2019, s.1022). Çalışmada negatif değerde olan öz kaynak kârlılı̆̆ı ve aktif kârlılığı verileri düzeltilerek uygulama yapılmıştır.

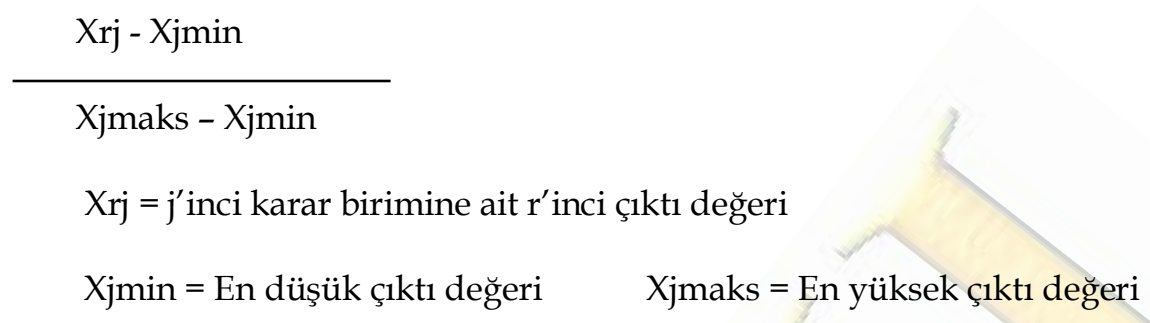

Ayrıca, analizde kullanılan işletme sayısı, toplam girdi ve çıktı sayısından en az 1 veya toplam girdi ve çıktı değişkenlerinin sayısının 2 katı olmalıdır (Büyükkeklik, Dumlu ve Evci, 2016, s.194). VZA uygulamasında 19 işletme, 3 girdi ve 2 çıtı kullanılmıştır. Formülleştirirsek; $3+2+1<19$. Diğer formül ise $(3+2) * 2<19^{\prime}$ dur. Kullanılan veriler her iki koşulu da sağlamaktadır.

CCR modeli, karar verme birimlerinin toplam etkinliklerini ifade eder. BCC modeli ise karar verme birimlerinin teknik etkinliğini anlatır. Toplam etkinlik, ölçek etkinliği ile teknik etkinlik değerlerinin çarpılması sonucunda oluşur. CCR ölçeğinde etkin bulunan karar verme birimi, BCC ölçeğinde de etkindir. Diğer yandan ise BCC ölçeğinde etkin olan karar verme birimi CCR ölçeğinde etkin olacağı anlamına gelmez (Öztürk, 2014, s.54). Etkin olan firmalar 1 ile ifade edilir. Etkin sinırda olanlar verimli, altında olanlar verimsiz kabul edilmektedir. VZA, araştırmacıların endişelerini azaltmak için kullanılır, analistler gelecek konusunda tahmin, tasarı ve tekliflerde bulunabilirler.

Tablo 5'te işletmelerin yapılan analiz sonucunda elde edilen etkinlik değerleri yer almaktadir. 
Tablo 5. VZA Sonucu İşletmelerin Etkinlik Değerleri

\begin{tabular}{|c|c|c|c|c|c|c|c|c|c|c|c|c|c|}
\hline Yillar & & 2017 & & & & 2018 & & & & 2019 & & & \\
\hline No & Firmalar & CCR & $\mathrm{BCC}$ & ÖLÇEK & & CCR & $\mathrm{BCC}$ & ÖLÇEK & & CCR & $\mathrm{BCC}$ & ÖLÇEK & \\
\hline 1 & ATEKS & 0,650 & 0,796 & 0,817 & irs & 0,543 & 0,792 & 0,685 & irs & 0,605 & 0,844 & 0,717 & irs \\
\hline 2 & ARSAN & 0,780 & 0,788 & 0,989 & irs & 0,658 & 0,812 & 0,810 & irs & 0,938 & 0,939 & 0,999 & irs \\
\hline 3 & BLCYT & 1 & 1 & 1 & - & 1 & 1 & 1 & - & 1 & 1 & 1 & - \\
\hline 4 & BRKO & 0,569 & 0,759 & 0,750 & irs & 0,418 & 0,768 & 0,545 & irs & 0,309 & 0,592 & 0,521 & irs \\
\hline 5 & BRMEN & 0,476 & 0,716 & 0,664 & irs & 0,488 & 1 & 0,488 & irs & 0,256 & 0,915 & 0,280 & irs \\
\hline 6 & BOSSA & 0,877 & 0,906 & 0,969 & irs & 1 & 1 & 1 & - & 1 & 1 & 1 & - \\
\hline 7 & DAGI & 0,666 & 1 & 0,666 & irs & 0,572 & 0,963 & 0,594 & irs & 0,847 & 1 & 0,847 & irs \\
\hline 8 & DERIM & 1 & 1 & 1 & - & 0,869 & 1 & 0,869 & irs & 0,906 & 1 & 0,906 & irs \\
\hline 9 & DESA & 0,705 & 1 & 0,705 & irs & 0,840 & 1 & 0,840 & irs & 0,972 & 1 & 0,972 & irs \\
\hline 10 & HATEK & 0,528 & 0,714 & 0,739 & irs & 0,600 & 0,755 & 0,795 & irs & 0,603 & 0,721 & 0,837 & irs \\
\hline 11 & KRTEK & 0,748 & 0,992 & 0,755 & in & 1 & 1 & 1 & - & 0,876 & 0,945 & 0,927 & irs \\
\hline 12 & KORDS & 0,835 & 0,868 & 0,962 & irs & 0,718 & 0,826 & 0,869 & irs & 0,827 & 0,915 & 0,904 & irs \\
\hline 13 & LUKSK & 0,807 & 1 & 0,807 & & 0,553 & 0,936 & 0,591 & irs & 0,795 & 0,890 & 0,894 & irs \\
\hline 14 & MNDRS & 1 & 1 & 1 & - & 0,301 & 1 & 0,301 & irs & 1 & 1 & 1 & - \\
\hline 15 & RODRG & 0,646 & 0,921 & 0,701 & irs & 0,852 & 1 & 0,852 & irs & 1 & 1 & 1 & - \\
\hline 16 & SKTAS & 0,365 & 0,828 & 0,440 & irs & 0,017 & 0,806 & 0,021 & irs & 0,367 & 0,736 & 0,499 & irs \\
\hline 17 & SNPAM & 1 & 1 & 1 & & 0,864 & 0,976 & 0,886 & irs & 1 & 1 & 1 & - \\
\hline 18 & YATAS & 1 & 1 & 1 & - & 1 & 1 & 1 & - & 1 & 1 & 1 & - \\
\hline \multirow[t]{2}{*}{19} & YUNSA & 0,986 & 1 & 0,986 & drs & 1 & 1 & 1 & - & 1 & 1 & 1 & - \\
\hline & Ort. & 0,770 & 0,910 & 0,840 & 5 & 0,700 & 0,928 & 0,744 & 5 & 0,805 & 0,921 & 0,858 & 7 \\
\hline
\end{tabular}

2017 yılı girdi ve çıktı değerlerinin VZA ile etkinlikleri değerlendirilip, girdi odaklı BCC ölçek ile analiz yapılmıştır. Analiz sonucunda BLCYT, DERIM, MNDRS, SNPAM, YATAS ve YUNSA firmaları etkinlik ölçümü 1 çıktığı için altı işletmenin etkin olduğu söylenir. VZA analiz sonuçları sabit ölçek getirisini de verdiği için CCR ölçekte ise BLCYT, DERIM, MNDRS, SNPAM ve YATAS firmaları etkin bulunmuştur. Fark olarak YUNSA firması CCR ölçekte etkin değilken, BCC ölçekte etkin bulunmuştur. Ölçek etkinlik değeri CCR / BCC şeklinde bulunduğu için her iki ölçekte etkin olan firmaların ölçek etkinlikleri 1'dır. Ölçek etkinlik sonuçlarını 
değerlendirecek olursak BLCYT, DERIM, MNDRS, SNPAM ve YATAS olmak üzere beş firma etkin kabul edilir.

2017 yılı için değişken ölçek etkinliği değerlendirildiğinde, 19 işletmenin 10 tanesinin etkinlik sınırının altında olduğu tespit edilmiştir. Etkin olmayan firmalar ATEKS, ARSAN, BRKO, BRMEN, BOSSA, HATEK, KRTEK, KORDS, RODRG, SKTAS olmak üzere on tanedir. Etkin olmayan işletmeler arasında bulunan ATEKS firmasının etkinlik değeri 0,796 çıkması piyasadaki en yakın karar verme biriminden 0,204 değer daha az verimlidir şeklinde ifade edilir.

Ortalama değerlere göre 19 işletmenin ölçek etkinlik ortalaması 0,840 değerine sahip olup bu değerin etkinlik sınırı olan 1'e yakın olması tekstil sektöründe faaliyet gösteren firmaların 2017 yılı için genel olarak etkine yakın çalıştıkların göstermektedir.

2018 yılında CCR (toplam verim) ölçekte değerlendirildiğinde etkin çıkan işletmeler BLCYT, BOSSA, KRTEK, YATAS ve YUNSA olmak üzere beş tanedir. BCC (teknik verim) ölçeği ile değerlendirildiğinde BLCYT, BRMEN, BOSSA, DERIM, DESA, KRTEK, MNDRS, RODRG, YATAS ve YUNSA olmak üzere on firma etkin bulunmuştur. Ölçek etkinlik değerlerine göre; BLCYT, DERIM, MNDRS, SNPAM ve YATAS işletmeleri etkin bulunmuştur.

Ortalama değerlerine göre 19 işletmenin 2018 yılı ölçek etkinlik ortalaması 0,744 çıktığından 2017 yılına kıyasla ölçek etkinliklerinin düştüğü söylenebilir.

2019 yılında CCR ölçeği ile etkinlik ölçümü yapıldığında BLCYT, BOSSA, MNDRS, RODRG, SNPAM, YATAS ve YUNSA olmak üzere yedi işletme etkin bulunmuştur. BCC ölçeği ile değerlendirildiğinde; BLCYT, SNPAM, YATAS, YUNSA, MNDRS, RODRG, BOSSA, DAGI, DERIM, DESA firmaları etkindir. Ölçek etkinlik değerlerine göre BLCYT, BOSSA, SNPAM, YATAS, YUNSA, MNDRS, RODRG olmak üzere yedi firma etkindir.

2019 yılının ortalama değerlerine göre 19 işletmenin ölçek etkinlik ortalaması 0,858 değerine sahip olması 2017 ve 2018 yıllarına kıyasla daha etkin olduğunu göstermiştir. 
Araştırmaya konu olan 2017, 2018 ve 2019 yılları genel olarak değerlendirildiğinde, BLCYT, YATAS firmaları düzenli olarak etkin bulunmuştur. Hem toplam etkinlik (CCR) değerleri hem de teknik etkinlik (BCC) değerleri 1 olduğu için ölçek etkinliğinden söz etmek mümkündür. 2017 ve 2018 yılında 5 firma, 2019 yılında ise 7 firma etkin bulunduğu için, işletmelerin yıllar itibariyle etkinliklerinin arttığını söylemek mümkündür. İncelenen yılların ölçek etkinliği değerlendiğinde ATEKS, ARSAN, BRKO, BRMEN, DAGI, DESA, HATEK, SKTAS, KORDS ve LUKSK işletmelerinin etkinliklerinin, diğer işletmelere kıyasla üç yılda da verimsiz olduğu gözlemlenmiştir.

\section{1. İşletmelerin Toplam Referans Sayıları ve Yoğunluk Değerleri}

VZA'da etkinlik, tüm karar verme birimleri birbirleriyle kıyaslanarak tespit edilmektedir. Etkin olmayan karar verme birimleri, etkin olabilmek için kendilerini etkin olan birimlere benzetirler. Bu benzetmeye çalıştıkları etkin karar verme birimlerinin oluşturduğu küme referans kümesini oluşturur. Etkin olmayan karar birimi farkl1 kombinasyonlarla kendisini etkin hale getirebilir.

VZA'nın BCC modelinde bulunan etkinlik değeri, CCR modeline göre eşit ya da fazla çıkmaktadır. BCC modeli yerel teknik verimlilik ölçerken, CCR modelinde genel teknik verimlilik değeri tespit etmektedir. İşletmelerin birinin BCC modeline göre etkinliği mevcutken, CCR modeline göre verimsiz çıkması o işletmenin lokal olarak verimli ancak genel olarak verimli çalışmadığını ifade eder. BCC modeli değişken ölçek varsayımı altında lokal teknik verimliliği belirtmektedir. Bu model verimsizliğin operasyonel sorunlardan $\mathrm{m}$ yoksa birimin içinde bulunduğu dezavantajlı durumlardan mı ya da her iki sebepten mi kaynaklandığı konusunda bilgi sunar. Etkin olmayan birimleri kıyaslama çalışmasında, yararlanılacak birimleri oluştururken, etkin birimlerden oluşan referans kümeleri de potansiyel karşılaştırma ortaklarını meydana getirmektedir (Tepe, 2006, s.105-106).

Karar birimi etkin ise göreli etkinlik ölçümü 1'e eşittir. Girdi ve çıtı değerlerinde değişiklik yapılmaz. Kendi referans kümesinde yine kendisi bulunur.

Tablo 6'da işletmelerin 2019 yılı referans ve yoğunluk değerleri verilmiştir. 
Tablo 6. 2019 Y1lı Referanslar ve Yoğunluk Değerleri (BCC)

\begin{tabular}{l|llllll}
\hline $\begin{array}{l}\text { 2019 } \\
\text { Firmalar }\end{array}$ & Referans & \multicolumn{5}{l}{ Referanslar } \\
\hline ATEKS & 0,516 & 0,063 & 0,422 & 3 & 15 & 6 \\
ARSAN & 0,514 & 0,211 & 0,275 & 3 & 6 & 14 \\
BLCYT & 1 & & & 3 & & \\
BRKO & 0,808 & 0,192 & & 3 & 15 & \\
BRMEN & 1 & & 15 & & \\
BOSSA & 1 & & 6 & & \\
DAGI & 1 & & 7 & & \\
DERIM & 0,265 & 0,735 & & 19 & 14 & \\
DESA & 1 & & & 9 & & \\
HATEK & 0,050 & 0,950 & & 15 & 3 & \\
KRTEK & 0,183 & 0,530 & 0,287 & 3 & 14 & \\
KORDS & 0,378 & 0,195 & 0,427 & 6 & 14 & \\
LUKSK & 0,839 & 0,161 & & 3 & 15 & \\
MNDRS & 1 & & & 14 & & \\
RODRG & 1 & & & 15 & & \\
SKTAS & 0,148 & 0,852 & & 15 & 3 \\
SNPAM & 1 & & & 17 & & \\
YATAS & 1 & & & 19 & \\
YUNSA & 1 & & & & \\
\hline
\end{tabular}

2019 yılı VZA sonucu, BCC modelinde etkin olmayan birimler için referans kümelerin ağırlıkları ile kıyaslama yaparken potansiyel kıyaslama ortakları gösterilmektedir. Her işletmenin referans kümesi farklı olmaktadır. ATEKS işletmesinin etkinlik değeri 1 olmadığı için referans kümesi olarak hedef değerler ve ağırlıkları belirlenmiştir. Bunlar; 3 numaralı BLCYT işletmesinin ağırlık değeri 0,516, 15. sıradaki RODRG firmasının değeri 0,063, 6. Sıradaki BOSSA firmasının değeri ise 0,422 oranındadir.

Etkinlik ağırlıkları 1 çıkanlar etkin oldukları için referans gösterilmeye ihtiyaçları yoktur. 1 dışında bulunan firmalar referans gösterilen ağırlıkları oranında iyileştirme gerektirmektedir. Referans gösterilen sayılar için eğer işletme karşısında kendi numarası mevcutsa etkindir. Fakat kendi numarası dışında sayı veya sayılar varsa etkin olmayan işletmedir ve kendisine referans gösterildiği işletmeyi anlatmaktadır. Özetle etkin olmayan karar verme birimlerini etkin hale getirebilmek için referans kümesinde bulunan işletmelerin ağırlıkları ve karar verme birimlerine benzetmek gerekmektedir. 
Toplam Referans Sayıları ise BCC ölçeğe göre, etkin olan işletmelerin, etkin olmayan işletmeler tarafından yıl içinde kaç kez referans gösterildiği toplam sayıyı belirtmektedir. Analiz kapsamındaki işletmelerin 2017-2019 yılları toplam referans sayıları Tablo 7'de verilmiştir.

Tablo 7. Toplam Referans Sayıları

\begin{tabular}{l|lllll}
\hline No & Firmalar & 2017 & 2018 & 2019 & Toplam \\
\hline 1 & ATEKS & 0 & 0 & 0 & 0 \\
2 & ARSAN & 0 & 0 & 0 & 0 \\
3 & BLCYT & 9 & 8 & 8 & 25 \\
4 & BRKO & 0 & 0 & 0 & 0 \\
5 & BRMEN & 0 & 4 & 0 & 4 \\
6 & BOSSA & 0 & 5 & 4 & 9 \\
7 & DAGI & 0 & 0 & 0 & 0 \\
8 & DERIM & 1 & 0 & 0 & 1 \\
9 & DESA & 1 & 4 & 0 & 5 \\
10 & HATEK & 0 & 0 & 0 & 0 \\
11 & KRTEK & 0 & 0 & 0 & 0 \\
12 & KORDS & 0 & 0 & 0 & 0 \\
13 & LUKSK & 7 & 0 & 0 & 7 \\
14 & MNDRS & 3 & 2 & 4 & 9 \\
15 & RODRG & 0 & 0 & 6 & 6 \\
16 & SKTAS & 0 & 0 & 0 & 0 \\
17 & SNPAM & 0 & 0 & 0 & 0 \\
18 & YATAS & 6 & 0 & 0 & 6 \\
19 & YUNSA & 0 & 0 & 1 & 1 \\
\hline
\end{tabular}

2017-2018-2019 yıllarında referans değeri toplamını açıklamak gerekirse, en verimli bulunan BLCYT en fazla referans gösterilerek 25 kere hedef seçilmiştir. BLCYT firmasından sonra 9 kere referans gösterilen BOSSA ve MNDRS firmalarıdır. 2017 yıl içinde hiç referans gösterilmeyen firmalar ise RODRG, SKTAS, HATEK, KRTEK ve KORDS firmalarıdır. 2018 yılı içinde; ATEKS, ARSAN, BRKO, DAGI, SKTAS, SNPAM, KORDS, LUKSK ve HATEK işletmeleri diğer işletmeler tarafından hiç referans gösterilmemiştir. 2019 yılı için ise ATEKS, ARSAN, BRKO, DERIM, HATEK, KRTEK, KORDS, LUKSK ve SKTAS işletmeleri hiç referans gösterilmemiştir.

\section{2. İşletmelerin Potansiyel İyileştirme Oranlarının Tespiti}

Aynı girdi ve çıktıya sahip karar birimlerinin göreceli etkinliği VZA ile karşılaştırılmaktadır. Her bir karar birimi için model çözülmektedir. Çözüm algoritmasında kullanılan doğrusal programlama tekniğinin çözümü sonucunda amaç fonksiyonu 1 değerine eşit ise etkin kabul edilir. Amaç fonksiyonu 1 değerine 
eşit olmayan karar birimi, etkin karar verme birimine benzeştirilmektedir. Etkin olmayan karar birimlerinin etkinliğinin bu şekilde sağlandığı varsayılır. VZA literatüründe potansiyel iyileştirme olarak adlandırılır. VZA modeli çözümü sağlandığında etkin karar birimlerine ait aylak değişkenlerin değeri 0 olmalıdır. Aylak değişken, girdi ve çıktı arasında kullanılmayan kapasiteyi göstermektedir. Etkin karar verme birimi için, tüm girdi ve çıktılar açısından kullanılmayan kapasite kalmadığ1 için aylak değer 0 çıkmaktadır. Sadece kendine ait olan aylak değişkenin değeri 1 olmaktadır. Bu şekilde referans seti oluşturulur. Etkin olmayan karar birimleri, etkin karar birimlerini referans alarak potansiyel iyileştirme gerçekleştirilir (Dă̆, 2011, s.60).

VZA ile etkinlik ölçümü yapıldığında etkin olmayan karar verme birimlerinin etkin olmalarını sağlamak için referans belirleme işleminin yanında, etkinlik sınırına nasıl varacakları da tespit edilebilir. Referans alınan karar verme birimlerindeki girdilerin ne kadar azaltılacağı çıktıların ise ne kadar arttırılması gerektiği bulunabilir. Potansiyel iyileştirme yüzdeleri bulunurken şu formülden yararlanabiliriz (Özçelik ve Avc1 Öztürk, 2019, s.1022);

Potansiyel İyileştirme Oranı $=($ Hedeflenen Girdi - Gerçekleşen Girdi) $/$ Gerçekleşen Girdi

Potansiyel iyileştirme yapılırken girdi oranları azaltılır, çıktı oranları arttırılarak normal düzeye gelmeleri sağlanır. VZA girdi odaklı BCC ölçeğinde 2017, 2018 ve 2019 yıllarına ait potansiyel iyileştirme oranları Tablo 8' de gösterilmektedir.

2017 yilında BLCYT, DAGI, SNPAM, YATAS, YUNSA, LUKSK, MNDRS, DERIM ve DESA şirketlerinin satışların maliyeti/satışlar, genel yönetim gideri/satışlar ve pazarlama satış dağıtım gideri/satışlar oranları 0 çıktığı için herhangi bir değişiklik yapılmasına gerek yoktur. Potansiyel iyileştirme yapılması gereken ATEKS firması VZA' da kullanılan tüm girdi oranlarını \%20 oranında azalttığı takdirde etkinlik sağlayacaktır. ARSAN tekstil etkinlik sağlamak için, satışların maliyeti/satışlar oranını \%21, genel yönetim gideri/satışlar oranını \%22 ve pazarlama satış ve dağıtım gideri oranını \% 20 oranında azaltması gerekmektedir. 
Tablo 8. Potansiyel İyileştirme Oranları

\begin{tabular}{|c|c|c|c|c|c|c|c|c|c|}
\hline \multirow{2}{*}{$\begin{array}{l}\text { YILLAR } \\
\text { FIRMALAR }\end{array}$} & \multicolumn{3}{|c|}{$2017-B C C$} & \multicolumn{3}{|c|}{$2018-B C C$} & \multicolumn{3}{|c|}{$2019-B C C$} \\
\hline & G1 & G2 & G3 & G1 & G2 & G3 & G1 & G2 & G3 \\
\hline ATEKS & $-0,20$ & $-0,20$ & $-0,20$ & $-0,21$ & $-0,20$ & $-0,21$ & $-0,16$ & $-0,16$ & $-0,16$ \\
\hline ARSAN & $-0,21$ & $-0,22$ & $-0,20$ & $-0,19$ & $-0,20$ & $-0,20$ & $-0,14$ & $-0,05$ & $-0,07$ \\
\hline BLCYT & 0,00 & 0,00 & 0,00 & 0,00 & 0,00 & 0,00 & 0,00 & 0,00 & 0,00 \\
\hline$B R K O$ & $-0,24$ & $-0,62$ & $-0,24$ & $-0,23$ & $-0,45$ & $-0,23$ & $-0,41$ & $-0,69$ & $-0,41$ \\
\hline BRMEN & $-0,28$ & $-0,29$ & $-0,29$ & 0,00 & 0,00 & 0,00 & $-0,09$ & $-0,74$ & $-0,09$ \\
\hline BOSSA & $-0,09$ & $-0,36$ & $-0,10$ & 0,00 & 0,00 & 0,00 & 0,00 & 0,00 & 0,00 \\
\hline$D A G I$ & 0,00 & 0,00 & 0,00 & $-0,04$ & $-0,04$ & $-0,08$ & 0,00 & 0,00 & 0,00 \\
\hline DERIM & 0,00 & 0,00 & 0,00 & 0,00 & 0,00 & 0,00 & $-0,03$ & 0,00 & $-0,02$ \\
\hline$D E S A$ & 0,00 & 0,00 & 0,00 & 0,00 & 0,00 & 0,00 & 0,00 & 0,00 & 0,00 \\
\hline HATEK & $-0,29$ & $-0,31$ & $-0,28$ & $-0,24$ & $-0,30$ & $-0,23$ & $-0,28$ & $-0,38$ & $-0,28$ \\
\hline KRTEK & $-0,01$ & 0,00 & 0,00 & 0,00 & 0,00 & 0,00 & $-0,05$ & $-0,07$ & $-0,05$ \\
\hline KORDS & $-0,13$ & $-0,13$ & $-0,13$ & $-0,17$ & $-0,18$ & $-0,18$ & $-0,09$ & $-0,08$ & $-0,08$ \\
\hline LUKSK & 0,00 & 0,00 & 0,00 & $-0,06$ & $-0,08$ & $-0,07$ & $-0,11$ & $-0,26$ & $-0,11$ \\
\hline MNDRS & 0,00 & 0,00 & 0,00 & 0,00 & 0,00 & 0,00 & 0,00 & 0,00 & 0,00 \\
\hline RODRG & $-0,08$ & $-0,32$ & $-0,08$ & 0,00 & 0,00 & 0,00 & 0,00 & 0,00 & 0,00 \\
\hline SKTAS & $-0,17$ & $-0,37$ & $-0,17$ & $-0,19$ & $-0,20$ & $-0,20$ & $-0,26$ & $-0,43$ & $-0,27$ \\
\hline SNPAM & 0,00 & 0,00 & 0,00 & $-0,02$ & $-0,22$ & 0,00 & 0,00 & 0,00 & 0,00 \\
\hline YATAS & 0,00 & 0,00 & 0,00 & 0,00 & 0,00 & 0,00 & 0,00 & 0,00 & 0,00 \\
\hline YUNSA & 0,00 & 0,00 & 0,00 & 0,00 & 0,00 & 0,00 & 0,00 & 0,00 & 0,00 \\
\hline
\end{tabular}

Not: Potansiyel iyileştirme yapılması gereken girdi açıklaması

G1: Satışların Maliyeti / Satış Hasılatı

G2: Yönetim Gideri / Satış Hasılatı

G3: Pazarlama Gideri / Satış Hasılatı

Tablo 8'de 2018 yıll potansiyel iyileştirme verileri incelendiğinde YATAS, YUNSA, BRMEN, BOSSA, DERIM, DESA, KRTEK, MNDRS, RODRG ve BLCYT firmaları girdi verilerinde herhangi bir değişiklik yapmasına gerek yoktur. 2018 yılı için SNPAM firması girdi olarak satışların maliyeti/satışlar oranını \% 2 , genel yönetim gideri/satışlar oranını \%22 azaltırken, pazarlama satış ve dağıtım gideri oranının da iyileştirme yapılmasına gerek yoktur.

2019 yılı verileri BCC ölçekte değerlendirildiğinde; BLCYT, BOSSA, DAGI, DESA, MNDRS, RODRG, SNPAM, YATAS ve YUNSA firmalarının VZA'da kullanılan girdi oranlarına potansiyel iyileştirme yapılması gerek yoktur. İşletmelerin 
etkinliğini sağlamak için potansiyel iyileştirme ihtiyacı duyulan ATEKS, ARSAN, BRKO, BRMEN, HATEK, KORDS, SKTAS işletmelerinin girdi oranlarının üçü ve DERIM firmasının da girdi 1 ve girdi 3 değerleri tablo $8^{\prime}$ de belirtilen oran kadar azaltılmalıdır.

\section{SONUÇ}

Bu çalışmada BIST'te işlem gören 19 tekstil işletmesinin 2017-2019 yıllarına ait etkinlik ölçümleri, ölçeğe göre sabit ve değişken getiri varsayımı altında ve girdi yönelimli olarak analiz edilmiştir. İşletmelerin 2017 yılı analizi sabit ölçek altında incelendiğinde 5 işletme, değişken ölçek altında incelendiğinde 9 işletme etkin bulunmuştur. 2017 yılı ölçek etkinliğine bakıldığında ise 5 işletme etkin çıkmıştır. 2018 yılında sabit ölçek varsayımı altında 5 işletme etkinken, değişken ölçek varsayımında 10 işletme etkin bulunmuştur. 2018 yılında ölçek verimliliğine bakıldı̆̆ında 5 işletme etkin bulunmuştur. 2019 yılı sabit ölçekte 7 işletme etkinken, değişken ölçekte 10 işletme etkin bulunmuştur. 2019 yılı ölçek verimliliği değerlendirildiğinde ise 7 işletmenin etkin olduğu sonucuna ulaşılmıştır. İncelenen üç yıl içerisinde BLCYT, YATAS işletmelerinde ölçek verimliliğinin etkin olduğu tespit edilmiştir. İncelenen yıllarda BLCYT işletmesi diğer işletmeler tarafından 25 kere referans gösterilerek birinci sırada yer almıştır.

Literatürde BIST Tekstil sektöründe VZA ile etkinlik ölçümüne yönelik çalışmalarda ulaşılan sonuçlar; analizlerin farklı değişkenler kullanılarak ve farklı dönemlerde yapılmış olmaları nedeniyle farklılıklar göstermektedir. İncelenen çalışmalarda (Kayalıdere ve Kargın, 2004; Çetin, 2006; Öztürk, 2014; Akın, 2018) farklı değişkenler ve farklı dönemler esas alınmasına rağmen bu çalışmada olduğu gibi araştırma kapsamındaki bazı işletmelerin göreli etkin olarak belirlendiği görülmüştür.

2017-2019 yıllarında etkin olmayan işletmelerin gerçekleşen girdi oranları doğrultusunda, hedeflenen girdiye ulaşmaları için potansiyel iyileştirme oranları tespit edilmiştir. Etkinlik sınırına ulaşmak için, işletme yöneticilerine yol gösterilmesi amaçlanmaktadır. 2019 için BRKO firması G1 (satışların maliyeti/satışlar)'de \%41 oranında, G2 (yönetim giderleri/satışlar)'de \%69 oranında, G3 (pazarlama 
giderleri)'te \%41 oranında, BRMEN firması en fazla G2'de \%74 oranında, firmas1 da G1 ve G3'te \%28, G2' de \%38 oranında azaltma yapması durumunda etkin konuma geçebilecektir. Bu işletmelerin satışlar içindeki satışların maliyeti, genel yönetim ile pazarlama satış ve dağıtım giderleri önemli yer tutmaktadır. Maliyet iyileştirmeleri VZA sonucunda tespit edilirken, etkin olmayan israf edilen kaynakların tespit edilmesi gerekmektedir. Genel olarak değerlendirildiğinde etkin olmayan işletmelere maliyetleri azaltma yoluna gitmeleri ve özellikle satışların maliyetini azaltacak stratejiler geliştirmeleri önerilebilir.

Tekstil işletmelerine uygulanan VZA sayesinde, karar verme birimlerindeki etkinsizlik miktarını tanımlayarak, alınması gereken tedbirler konusunda işletme yöneticilerine yol gösterilmektedir. Performans ölçümü ile yüksek seviyede gösterilen performanslar, rekabet edilebilirlik açısından da başarı faktörüdür. Bu nedenle mevcut performansı geliştirerek işletmenin etkinliğini arttırmak günümüzde önemli bir amaçtır. BIST'te işlem gören tekstil işletmelerine uygulanan VZA sonucunda, etkin olmayan işletmelerin etkin duruma gelmesi ve rekabet açısından işletmelerin performansları hakkında yorumlar yapılarak literatüre katkı sağlanmaya çalışılmıştır.

Bu çalışma tekstil sektörlerine ilişkin yıllar bazında uygulanabildiği gibi, farklı sektörlere de uygulanarak sektörler arası karşılaştırma yapılmasına olanak sağlamaktadır. Ayrıca yapılacak yeni çalışmalarda girdi ve çıktı veri setlerini veya yılları değiştirerek analiz ve değerlendirme yapılabilmesi ve VZA ile farklı analiz yöntemlerinin de beraberinde uygulanması mümkündür. Kısacası VZA mevcut durumdaki girdi çıktıları tespit ederek, israf edilen, gereksiz kullanılan kaynakların daha bilinçli bir şekilde yönetilip kullanılmasını sağlamaktadır. 


\section{KAYNAKÇA}

Akın, N. G. (2018). Dokuma Sektöründe Veri Zarflama Analizi Ve Malmquist Topla Faktör Verimlili Endeksi. Uluslararası Ekonomi, İşletme Ve Politika Dergisi, 2 (2), 241-260.

Akyüz, K. C., Yıldırım, İ. \& Balaban, Y. (2015). Kağıt Sektöründe Yer Alan Firmaların Veri Zarflama Analizi Yardımıyla Etkinliklerinin Ölçümü. Uluslararası İktisadi Ve İdari İncelemeler Dergisi, (14), 23-38.

Alrashidi, A. N. (2015). Data Envelopment Analysis for Measuring the Efficiency of Head Trauma Care İn England And Wales. Doctoral Thesis, University of Salford Manchester, England.

Bakırcı, F. (2006). Sektörel Bazda Bir Etkinlik Ölçümü: Vza İle Bir Analiz. Gaziosmanpaşa Üniversitesi İktisadi Ve İdari Bilimler Dergisi, 20(2), 199-217.

Behdioğlu, S. \& Özcan, G. (2009). Veri Zarflama Analizi Ve Bankacılık Sektöründe Bir Uygulama. Süleyman Demirel Üniversitesi İktisadi Ve İdari Bilimler Fakültesi Dergisi, 14(3), 301-326.

Budak, H. (2010). Veri Zarflama Analizi Ve Hisse Senedi Seçiminde Bir Uygulama. Yüksek Lisans Tezi, Gazi Üniversitesi, Ankara.

Büyükkeklik, A., Dumlu, H. \& Evci, S. (2016). Measuring the Efficiency of Turkish Smes: A Data Envelopment Analysis Approach. International Journal of Economics and Finance, 8(6), 190-200.

Chandra, P., Cooper, W. W., Li, S. \& Rahman, A. (1998). Using Dea To Evaluate 29 Canadian Textile Companies - Considering Returns to Scale. International Journal of Production Economics, 54 (2), 129-141.

Cooper, W. W., Seiford, L. M. \& Tone, K. (2000). Data Envelopment Analysis: A Comprehensive Text with Models, Applications, References and Dea-Solver Software. Boston: Kluwer Academic Publishers.

Çetin, A. C. (2006). Türk Tekstil Sektörü Ve Türk Tekstil Firmalarının Etkinlik Düzeylerinin Belirlenmesi. Afyon Kocatepe Üniversitesi İktisadi Ve İdari Bilimler Fakültesi Dergisi, 8(2), 255-278.

Coşkun Arslan, M. \& Karkacıer, A. (2019). Dijital Dönüşüm Sürecinde Yönetim Muhasebesinin Geleceğini Etkileyen Faktörlere Kavramsal Bir Bakış. Avrasya Sosyal Ve Ekonomi Araştırmaları Dergisi, 6(6), 430-442.

Dağ, S. (2011). Türkiye' deki Katılım Ve Mevduat Bankalarının Etkinliklerinin Veri Zarflama Analizi Yöntemiyle Karşılaştırılması. Yüksek Lisans Tezi, Dumlupınar Üniversitesi, Kütahya.

Demir, N. (2013). Türk Tekstil Sektöründe Veri Zarflama İle Performans Analizi. Yüksek Lisans Tezi, Adnan Menderes Üniversitesi, Aydın.

Dinçer, S. E. (2008). Veri Zarflama Analizinde Malmquist Endeksiyle Toplam Faktör Verimliliği Değişiminin İncelenmesi Ve İmkb Üzerine Bir Uygulama. Marmara Üniversitesi İktisadi Ve İdari Bilimler Fakültesi Dergisi, 15(2), 825-846.

Ergin, H. \& Elmacı, O. (1999). Maliyet Ve Yönetim Muhasebesinde Yeni Açılımlar: Stratejik Yönetim Muhasebesi. Dumlupınar Üniversitesi Sosyal Bilimler Dergisi, (3), 17-50.

Erin, M. Z. (2010). Veri Zarflama Analizi İle İl Özel İdarelerinin Etkinliğe Dayalı Performansının Ölçümü. Yüksek Lisans Tezi, Afyon Kocatepe Üniversitesi, Afyon.

Frehe, T. (2013). An Efficiency Evaluation of Small and Medium Sized İndustries By Data Envelopment Analysis. Master Thesis, University of Vaasa, Finland.

Güran, M. C. \& Tosun, M. U. (2005). Türkiye Ekonomisinin Makro Ekonomik Performansı: 1951-2003 Dönemi İçin Parametrik Olmayan Bir Ölçüm. Ankara Üniversitesi Siyasal Bilgiler Fakültesi Dergisi, 60(4), 89-115.

Horngren, C. T., Datar, S. M. \& Rajan, M. V. (2015). The Manager and Management Accounting (15. Bs.). England: Pearson Education Limited.

Javid, R. (2018). Data Envelopment Analys - Efficiency Analysis On 17 Middle-Sized Hospitals İn Sweden. Master Thesis, Lund University, Sweden.

Jorge, S., Negas, E. R. \& Santos, L. C. (2013). Efficiency Measures in the Agricultural Sector with Applications. Netherlands: Springer. 
Kayalıdere, K. \& Kargın, S. (2004). Çimento Ve Tekstil Sektörlerinde Etkimlik Çalışması Ve Veri Zarflama Analizi, Dokuz Eylül Üniversitesi Sosyal Bilimler Enstitüsü Dergisi, 6 (1), 196-219.

Kaygusuz, S. Y. \& Dokur, Ş. (2015). Yönetim Muhasebesi. Bursa: Dora.

Kecek, G. (2010). Veri Zarflama Analizi Teori Ve Uygulama Örneği. Ankara: Siyasal Kitabevi.

Kıran, B. (2008). Kalkınmada Öncelikli İllerin Ekonomik Etkinliklerinin Veri Zarflama Analizi Yöntemi İle Değerlendirilmesi. Yüksek Lisans Tezi, Çukurova Üniversitesi, Adana.

Oruç, K. O. (2008). Veri Zarflama Analizi İle Bulanık Ortamda Etkinlık Ölçümleri Ve Üniversitelerde Bir Uygulama. Doktora Tezi, Süleyman Demirel Üniversitesi, Isparta.

Özçelik, F. \& Avcı Öztürk, B. (2019). Girdi Olarak Maliyetlere Yönelik Veri Zarflama Analizi Modelleri İle Göreli Etkinlik Analizi. İşletme Araştırmaları Dergisi, 11(2), 1011-1028.

Özçelik, F. \& Kandemir, B. (2017). Veri Zarflama Analizi Ve İmalat Sektöründe Bir Uygulama. Süleyman Demirel Üniversitesi İ̈BF Dergisi, 22(1), 43-53.

Özden, Ü. H. (2008). Veri Zarflama Analizi (Vza) İle Türkiye' deki Vakıf Üniversitelerinin Etkinliğinin Ölçülmesi. İstanbul Üniversitesi İşletme Fakültesi Dergisi, 37(2), 167-185.

Özden, A., Özer, O. O. \& Çinar, G. (2012). Etkinlik Ölçümünde Kullanılan Bir Bilgisayar Yazılımı: Deap 2.1. In 10. Ulusal Tarım Ekonomisi Kongresi 772-780. Konya.

Öztürk, O. (2014). Türk Tekstil Ve Hazır Giyim Firmalarının 2012 Yılı İhracat Etkinliklerinin Veri Zarflama Analizi Ve Analitik Hiyerarşi Süreci Yöntemleriyle Değerlendirilmesi. Yüksek Lisans Tezi, Eskişehir Osmangazi Üniversitesi, Eskişehir.

Pekuri, A., Haapasalo, H. \& Herrala, M. (2011). Productivity and Performance Management Managerial Practices in The Construction Industry. International Journal of Performance Measurement, 1, 39-58.

Perçin, S. \& Ustasüleyman, T. (2007). Tekstil Ve Gıda Sektöründe Etkinlik Ölçümü: Veri Zarflama Analizi Ve Malmquist Tfp Endeksi Uygulaması, İktisat İşletme Ve Finans İnceleme Araştırma Dergisi, 22(250), 154-171.

Prokopenko, J. (2011). Verimlilik Yönetimi Uygulamah El Kitabı. (O. Baykal, N. Atalay Ve E. Fidan, Eds.) (7. Bs.). Ankara: Mpm.

Sarıçam, C. \& Erdumlu, N. (2012). Evaluating Efficiency Levels Comparatively: Data Envelopment Analysis Application for Turkish Textile and Apparel Industry. Journal of Industrial Engineering and Management, 5(2), 518-531

Sayıştay (2003). Sayıştayın Performans Ölçümüne İlişkin Ön Araştırma Raporu. Retrieved from Https://Www.Sayistay.Gov.Tr/Tr/Upload/95906369/Files/ Yayinlar /Sayıştay_Performan S_Olcumu_Arastirma_Raporu.Pdf.

Seyrek, İ. H. \& Ata, H. A. (2010). Veri Zarflama Analizi Ve Veri Madenciliği İle Mevduat Bankalarında Etkinlik Ölçümü. Bddk Bankactlı Ve Finansal Piyasalar Dergisi, 4(2), 66-84.

Şenol, Z. \& Ulutaş, A. (2018). Muhasebe Temelli Performans Ölçümleri İle Piyasa Temelli Performans Ölçümlerinin Critic Ve Aras Yöntemleriyle Değerlendirilmesi. Finans Politik Ve Ekonomik Yorumlar Dergisi, 641, 83-102.

Tepe, M. (2006). Kıyaslama Çalışmasında Veri Zarflama Analizi Kullanımı. Yüksek Lisans Tezi, İstanbul Teknik Üniversitesi, İstanbul.

Usman, M., Hassan, A., Mahmood, F. \& Shadid, H. (2014), Performance of Textile Sector of Pakistan: Application of Data Envelopment Analysis Approach, International Review of Mangement and Business Research, 3(3), 1683-1698.

Uyargil, C. (2014). Performans Yönetimi Sistemi (4. Bs.). İstanbul: Beta.

Verma, S., Kumawat, A. \& Biswas, A. (2015). Measurement of Technical Efficiency Using Data Envelopment Analysis: A Case of Indian Textile Industry. 3rd International Conference on Advances in Engineering 
Sciences \& Applied Mathematics (ICAESAM'2015) March 23-24, London (UK).

Yavuz, S. \& İşçi, Ö. (2013). Veri Zarflama Analizi İle Türkiye'de Gıda İmalatı Yapan Firmaların Etkinliklerinin Ölçülmesi. Dumlupınar Üniversitesi Sosyal Bilimler Dergisi, (36), 157-174.

Yürüşen, S. (2011). Veri Zarflama Analizi İle Bayi Performansının Hesaplanması: Otomotiv Sektöründe Bir Uygulama. Yüksek Lisans Tezi, İstanbul Teknik Üniversitesi, İstanbul. 